\title{
Synergetic Linguistics as a New Philosophy of Language Studies
}

\author{
Olga KLYMENKO \\ Zaporizhzhia National University, Zaporizhzhia, Ukraine \\ Saniya YENIKEYEVA \\ Zaporizhzhia National University, Zaporizhzhia, Ukraine
}

\begin{abstract}
The article deals with the new philosophical interpretation of the structural organization and development of language as a synergetic system. Consideration of language as a complex open non-linear fluctuating system, which functions and develops according to synergetic principles, promotes the formation of a new transdisciplinary science - synergetic linguistics. The formation and development of the new branch of applied linguistics depends on the study of various lingual phenomena from the standpoint of synergetic philosophy and methodology. The use of synergetic methodology for language studies proves the appropriateness of so-called "non-systemic", "irregular", "transitional" lingual phenomena and processes, proves the necessity of their existence in a functioning language, determines mechanisms of language supersystem self-organization, provides opportunities for determining the trends of its development.
\end{abstract}

Index Terms - synergetic linguistics, fluctuation, attractor, self-organization, deviation

\section{INTRODUCTION}

At all periods of the history of humanity, science as a social phenomenon used to solve different current economic, political, and social problems of society, using the topical philosophic theories, research paradigms, and methods which dominated at that time. In the second half of the $\mathrm{XX}^{\text {th }}$ century, the famous Belgian physicist and philosopher I. Prigogine developed a new concept of understanding the nature and essence of the world as an open non-linear multivariate system, capable of self-organization and self-development. After studying thermodynamic systems and discovering the principles of their development via self-organization I. Prigogine put forward a hypothesis about the relevance of his theory of instability and self-organization to any systemic objects of material and immaterial nature (Prigogine, 1989).

For naming the science that studied the laws of self-organization in complex open physico-chemical systems, far from the state of equilibrium, the German theoretical physicist H. Haken introduced the term "synergetics" (Haken, 1977, 1987, 1990). Extrapolation of synergetic ideas to the study of various phenomena of animate and inanimate nature contributed to the evidence of complex systems' isomorphism and confirmed trans-disciplinarity and universalism of this new scientific theory.

Since then synergetics has demonstrated its enormous cognitive and heuristic biases, opened new horizons in forecasting, thus gaining many supporters among scientists. It has become a kind of philosophy, which aims to synthesize a huge variety of sciences, both fundamental and applied, based on the essential unity of animate and inanimate objects of reality. The principles of a synergetic worldview correlate with the philosophical ideas of holism asserting the universal character of all systemic objects' structural organization and laws of evolution. H. Knyazeva emphasizes that the development of synergetics "means a radical shift of paradigm, a conceptual transition from being to becoming, from stability to sustainability, from images of order to chaos generating new ordered evolving structures, from evolution to co-evolution, reciprocal evolution of different complex systems" (Knyazeva, 2002, p. 403).

It is necessary to note that the peculiarity of synergetics as a new scientific branch is that it does not deny the laws of classical science, but complements and completes them by offering a look at the studied objects from a new angle of research. Synergetics, or the theory of self-organization of systems, deepens and expands our knowledge of the world, involving in the circle of scientific research, phenomena that, although not deterministic and logically explainable, but are an integral part of our lives.

\section{Methodology}

Synergetics is expanding its "borders" constantly and continuously due to the universal character of the laws of selforganization and evolution, its patterns and methods, developed within its framework (Prigogine, 1977; Budanov, 2006). Researchers compare the growth of areas of application of synergetic models and methods with the expansionary policy of some states (Knyazeva, 2001, p. 99). The social sciences have recently become one of the "vectors of expansion" of 
synergetics. Thus, there is an active integration of synergetics in the linguistic researches, which mainly transfers its ideas, methods, and patterns in the study of various linguistic phenomena.

There is a wide application of the synergetic approach in different fields of modern linguistics: history of language (Dombrovan, 2014, 2015, 2018), theory of communications (Aisyah, Jin, 2017; Tarasova, 1996, 2000), cognitive linguistics (Jia, Liang, 2020; Prikhodko, 2015; Veremchuk, Yenikeyeva, 2020), text linguistics (Pikhtovnikova, 1999, 2011, Pikhtovnikova, Yaremchuk, 2012; Semenets, 2004, 2015; Simonov, 2013), lexicology (Kiyko, 2014, 2016; Klymenko, 2018; Lan-xia, 2014), word-formation studies (Yenikeyeva, 2006, 2011, 2015; Yenikeyeva, Klymenko, 2021), syntax (Prikhodko, 2003, Yenikeyeva 2018), discourse analysis (Pikhtovnikova, 2005, 2009, 2015), psycholinguistics (Kuzeev, 2020), language learning (Buivydienė, Mamčenko, Piscikiene, Šustickienė, 2017; Cabau, 2016).

However, the present achievements of scientists in the studies of linguistic phenomena, made by extrapolating the ideas and principles of synergetics, can be considered only the first steps in the formation of a new scientific paradigm of linguistics -synergetic linguistics.

On the one hand, continuation of research work in this direction should expand our heuristic possibilities and extend our understanding of the advantages of the new scientific paradigm, and on the other - to promote the further development of linguistics as a science. Scientists still have to solve various problems of this new branch of linguistics, in particular, the problem of scientific reasoning of the synergetic methodology in the study of linguistic phenomena; determining the mechanisms of self-organization at micro-, macro- and super-levels of a language system; the problem of defining the role of "non-systemic", "irregular", transient phenomena in language and explaining their necessity for a language development, etc. The novelty of the synergetic paradigm and its linguistic perspectives determine the relevance of further research in this field.

The purpose of the proposed article is to determine the specificity of the implementation of synergetic principles in linguistic studies and to characterize synergetic linguistics as a branch of applied linguistics. To achieve this goal the following tasks are to be completed: to identify the features of synergetics as a new research paradigm; to review the main principles of synergetics; to determine the core subject of synergetic linguistics; to prove the relevance of synergetic research methods for language phenomena and processes.

Research Methods. To achieve this goal, the following methods were used: the methods of collection and critical studies of theoretical material dealing with philosophic and methodological aspects of synergetics were to create the general concept of universal and interdisciplinary character of its principles; the extrapolation method was to confirm the relevance of the synergetics' ideas and principles to studies of various language phenomena and processes and to outline the possibility of cooperation between synergetics and linguistics; the description of language as a comlpex open non-equilibrium system with non-linear ways of development was to prove its synergetic nature, principles of structural organization and evolution.

\section{RESULTS AND ANALYSIS}

As scientists claim, synergetics is "one of the successive stages of paradigmatic non-classical knowledge" (Vasilkova, 1999, pp. 28-29; see also Budanov, 2009, p. 5). On the contrary to the classical paradigm with its cult of rationality and knowledge of the world through deterministic views, synergetics looks behind the world organized by the rules of human mind into the "irrational" real world.

If the scientific paradigm is understood as "a way of cognition and understanding the world, which determines the general research principles of a certain object in different sciences" (Selivanova 2006, p. 409), we can assume that synergetics is a new scientific paradigm. It has the characteristics of a new paradigm because it focuses on a set of facts ("objects of study" (Vasilkova, 1999, p. 29)), which have not been previously studied by classical science. Its novelty is to recognize the regularity of the existing heuristic dominants of contingency, irreversibility, instability, non-linearity, unpredictability, as well as to determine their role in evolution associated with self-organization and self-regulation of systems.

Unlike classical science, which understands "the world as an absolutely correct and regulated process, and nature as a dead, passive foundation operating automatically" (Vasilkova, 1999, p. 25), and recognizes the cult of rationality in science, giving a human the right to transform the world purposefully, synergetics considers the world as an integer consisting mainly of complex, open, instable systems capable of intensive exchange of substance, energy and information inside themselves, with other systems and with the environment, and are characterized by non-equilibrium, non-linearity, spontaneity, randomness and irreversibility of changes.

Synergetics is usually considered in three aspects of its interaction with society: 1) synergetics as a picture of the world; 2) synergetics as a methodology; 3) synergetics as a science (Budanov, 2006, p.146). It is a new philosophy proclaiming "a new dialogue of man with nature" (Knyazeva, Kurdyumov, 2002, p. 8). It is also a transdisciplinary branch of science, which aims to develop generalized theoretical models and uses them as a method of research of complex (hierarchically organized), open (capable of exchanging substance, energy, and information with the environment), dissipative (non-equilibrium) systems of inanimate and animate nature. Synergetics, or the theory of selforganization, the basic principles of which were originally developed in the research of physical phenomena, has now become transdisciplinary scientific paradigm. Extrapolation of synergetic ideas in the study of various phenomena of 
animate and inanimate nature contributed to revealing the isomorphic character of complex, open, non-linear systems' "behavior". And the universal laws of evolution and self-organization of such systems, the widespread use of models developed within this scientific paradigm, contributed to the development of both the theory of synergetics and different applied sciences.

As scientists prove, the principles of synergetics operate at the level of knowledge, which covers a number of scientific disciplines that study different areas of reality (Knyazeva, 2001, p. 102). In this regard, it is quite logical to claim the limits of synergetics and the areas of its competence. There waiting for solution the problems of cooperation of synergetics as a new science, methodology and worldview with various natural and human sciences (in particular, the relevance of scientific methods worked out and tried out by natural sciences in the study of such a unique social phenomenon as language).

Consequently, it should be emphasized that synergetics is a young interdisciplinary branch of science which is rapidly developing, that's why it is impossible to limit the scope of its activities and to determine clearly what to do or not to do. Due to its universal and transdisciplinary character, synergetics has "soft" boundary lines and is constantly expanding (Knyazeva, 2001, p. 101). The use of synergetic models and methods in the study of systemic phenomena of animate and inanimate nature, can become a guarantee of expanding the scope of new scientific paradigm and deepening the fundamentals of its theory.

Among the components of authentic synergetics, the scholars mark the innovative, universal synergetic methodology, which suggests a new look at well-known facts and new decision to the problems that were not solved within the classical scientific paradigm. By interpreting and filling the universal synergetic models with the specific scientific content, considering them in a certain disciplinary context, scientists solve the priorities of particular areas of knowledge and rethink the essence of known phenomena and processes, thereby strengthening the position of synergetics.

Scholars regard synergetics as an interdisciplinary phenomenon in culture having subject knowledge, philosophical reflection, mathematical modeling as constituent parts of it (Malinetsky, 2005, p. 13). The relevance of synergetics in humanitarian studies only as a methodology of scientific research does not mean the absolute irrelevance of its other components. As already mentioned, synergetics is now a rapidly developing and expanding branch; so potentially it could be implemented in many other fields. The fact that mathematical modeling has not been used in the study of linguistic phenomena does not mean that it is completely impossible. We consider, that according to its architectonics, principles of functioning and development, language is a classic example of a synergetic system and the fact, that the relevance of mathematical models hasn't been proven yet, cannot doubt its synergetic nature.

\section{DiscUSSION}

It should be considered that recently not only synergetics but also linguistics has demonstrated its "expansionary" potential. As A. D. Belova observed, "the period of "pure linguistics", which did not go beyond the language environment, is ending, and giving way to "linguistic expansion": analyzing the complex mechanisms of functioning the natural languages under the influence of extralingual factors, linguistics will be forced to interfere into the "living space" of other sciences" (Belova, 2003, p. 264). Thus, both synergetics as a new scientific branch and linguistics, which has recently shown a tendency to cooperate with other sciences, demonstrate their readiness to create symbiosis. Such a "union", in our opinion, is "mutually beneficial", because in this way, synergetics expands the scope of relevance of its ideas and principles, and linguistics acquires a new methodology that allows a deeper analysis of its nature and essence, understanding the mechanisms of its development. The "intersection area" between these two scientific paradigms is synergetic linguistics.

The scientists who have used the new scientific paradigm without fear of being accused in "incorrect extrapolation" of synergetic ideas to the study of social life have proved that it has great potential in the study of phenomena that previously did not find a rational explanation, were considered random and anomalous. The system of synergetic principles is the core of the methodology for studying systems of different nature, including language. In our opinion, the use of ideas and principles of synergetics in the study of language and linguistic processes can help solve a number of problems that have not found logical explanation within the dominant classical scientific paradigm. For a long time, scientists, realizing that the world around us is too complex and the human mind is clearly unable to cognize it, have sought to establish simple logical, rational patterns, ignoring phenomena and processes that had no logical explanation, and therefore considered random.

For many centuries such a logically inexplicable lingual phenomenon has been the Great Vowel Shift in Germanic languages. There were no logical reasons for this modification of sounds. It seemed irrational that transformation of vowels led to the restructuring the phonetic systems of Germanic languages, and then, with the effect of a chain reaction, the other macro-systems of these languages, morphological and lexical ones above all. The linguistics as a science has been restricted to find the correspondences of vowels in the phonetic systems of each of the Germanic languages at the previous stage of existence and after the transformation. The use of synergetic models in the study of this phenomenon gives scientists the opportunity to study the nature of transformations, to see the regularity of such transformations in lingual dynamic systems. Thus, at a certain stage of its history in some parts of the phonetic system there began to 
appear deviations from the existing traditional pronunciation of vowels in certain positions. Due to the increase of such deviations, the phonetic system went into a state of fluctuation.

In synergetics, fluctuation is understood as random deviations of instantaneous values of magnitudes from their average values, that is from the state of equilibrium. "Fluctuations," scientists emphasize, "can lead the system to directed changes, to the emergence of various new, relatively stable structures, not just to the previous state of equilibrium. If the fluctuation is not intensive enough, the system will return to the previous equilibrium structure, "roll down" on the previous attractor" (Knyazeva, Kurdyumov, 2002, p. 24).

We can assume that during the period of $\mathrm{XIV}-\mathrm{XVI}{ }^{\text {th }}$ centuries, phonetic macro-systems of Germanic languages were in a state of chaos: in addition to the traditional, there arose another, innovative pronunciation of the vowel in the phonetic word, and various social, regional and other groups of native speakers could use the traditional, new, or even both pronunciations at the same time. As a result the innovative variants became regular and gradually turned into a standard. The chaos in this case had the constructive character and eventually brought the system to a new attractor. Since the fluctuations were strong, the system could not return to its previous state and gradually began to self-organize, moving to a qualitatively new stage of existence.

Such processes of self-regulation and self-organization at different levels of the language super-system occur constantly, but the intensity of these processes in different areas is not the same. We believe that nowadays "phonetic revolutions" similar to the Great Vowel Shift are hardly possible, because the phonology of literary language is strictly regulated and respected, since audio and audio-visual media every day represent the best examples of standardized literary speech. In contrast to the ancient times, when such technologies did not exist, it was impossible to codify the phonology of speech of representatives living in different regions and belonging to different social backgrounds. Nowadays, native speakers of different languages have the opportunity to compare their speech with the best examples represented by radio and television, documentary, and feature films. Due to this, the development of phonetic macrosystems of modern Germanic languages has a slowed-down evolutionary character.

In all times, the most intensively changing endo-system of any language was lexical macro-system, which has constantly been enriching with new naming units reflecting historic events, scientific and technological achievements, innovations in political, economic, and cultural life of society. It is remarkable that, nowadays the most active parts of the Modern English language super-system, which are developing rapidly and intensively, are the lexical and wordformation macro-systems. This phenomenon can be explained by the fact that they remain "the most open" to the exchange of substance, energy, and information with the environment surrounding a certain language. The enrichment of the language vocabulary can occur under the influence of the social environment or due to material units (words) borrowed from the lexical macro-systems of other language super-systems, or by forming neologisms from own resources within a given lingual super-system.

The neological boom observed in many languages of the world, and especially in English, is an adequate response of language super-systems to scientific and technological, economic, political, ecological changes in modern human life. Under the influence of social factors, languages are constantly changing and self-organizing. As a result of the quantitative growth of the vocabulary, the ways and means of new lexemes' formation are also improving and the quantity of new word-formation tools is increasing. Therefore, due to the effects of the external environment, the process of self-regulation and self-organization within the lexical and word-formation macro-systems and the language super-system as a whole is carried out.

A new look at the principles of organization of the language system, at the phenomena of order and chaos, determinism and randomness observed in the process of its functioning, at the laws of development and evolution of language as a system capable of self-organization and self-regulation, allows comprehensive and complete reproduction of architectonics (organization) and autopoesis (self-impovement) of the language super-system and endo-systems that are parts of it.

Language is a classic example of a synergetic system. By its structure, it is a super-system consisting of hierarchically organized macro- and micro-systems, each of which, like the language super-system as a whole, is characterized by openness - the ability to exchange substance, energy, and information with the environment. This exchange occurs between super-systems of the same order (for example, between different languages, resulting in borrowing), between macro-systems within a single lingual super-system (for example, the phenomenon of functional transorientation: affixalization of lexems, lexicalization of affixes, lexicalization of syntactic constructions), between language micro-systems (for example, functional transposition of lexemes - conversion).

The application of synergetic principles in the research of linguistic phenomena has made it possible to understand and explain the evolution mechanism of the language system, how it manages to maintain itself in a state of dynamic balance, while its constituents function and while they are functioning, they change. Synergetics explains the regularity of the existence of linguistic phenomena, which were previously considered "not-systemic" and even marginal.

Despite its novelty, synergetic linguistics has gained many supporters and followers. From our perspective, the application of ideas and principles of synergetics in the study of linguistic phenomena has great prospects. Understanding the synergetic nature of language lets see more clearly the principles of its organization as a system, identify potential sources of its development, determine the role of "non-systemic" transitional phenomena in the 
evolution of the language system, reveal the mechanisms that ensure its relative stability and permanent development, prove scientifically the influence of social factors on the processes of self-organization of the language system.

\section{CONCLUSIONS}

Thus, synergetics as a philosophy has opened new opportunities in the study of social phenomena. Synergetic methodology is widely used in the human sciences. The use of synergetic ideas in the language research has contributed to the formation of synergetic linguistics (or linguosynergetics), which is defined as an applied linguistics which gives synergetic description of lingual phenomena and processes. Cooperation between synergetics and linguistics has a great perspective, as the new synergetic methodology opens wide opportunities in determining the nature and essence of many lingual phenomena, the existence of which has not found a logical explanation within the classical scientific paradigm. Moreover, the study of systemic, regular linguistic phenomena in terms of synergetics will significantly complete our knowledge about them.

The novelty of the synergetic paradigm makes promising the study of lingual phenomena using the innovative methodology. The formation and development of synergetic linguistics as a new branch of applied linguistics depends on the study of various lingual phenomena from the standpoint of synergetic philosophy and methodology. The perspective of the further research is on the analysis of word-forming phenomena and processes of Modern English by implementing the ideas and principles of the theory of self-organization.

\section{REFERENCES}

[1] Aisyah, A., \& Jin, N. Y. (2017). K-Pop V Fansubs, V LIVE and NAVER Dictionary: Fansubbers' Synergy in Minimising Language Barriers. 3L: Language, Linguistics, Literature, 23(4).

[2] Belova, A. D. (2003). Lingvisticheskiye aspekty argumentatsii. (Linguistic Aspects of Argumentation) Kyiv: Logos. 480.

[3] Budanov, V. (2006). Metodologiya i printsipy sinergetiki. (Methodology and Principles of Synergy). Philosophy of Education, 3. 143-172.

[4] Budanov, V. (2009). Metodologiya sinergetiki v postneklassicheskoy nauke i v obrazovanii. (Methodology of Synergetics in Post-non-classical Science and Education). Moscow: Publishing house LKI. 240.

[5] Buivydienè, R., Mamčenko, J., Piscikiene, I., \& Šustickienė, B. (2017). Synergy of language learning and virtual learning platforms in studies. Society. Integration. Education. Proceedings of the International Scientific Conference, 2, 388-396. doi:https://doi.org/10.17770/sie2017vol2.2356

[6] Cabau, B. (2016). Language and Content Courses: A Plea for Synergy in Academic Programmes. Interface Journal of European Languages and Literatures, 1(01).

[7] Dombrovan, T. I. (2014). Sinergeticheskaya model' razvitiya angliyskogo yazyka. (A Synergistic Model for the English Language Development). Odessa: KP OGT. 399.

[8] Dombrovan, T. I. (2015). Istoriya angliyskogo yazyka kak ob"yekt issledovaniya v diakhronicheskoy lingvosinergetike. (History of the English Language as an Object of Research in Diachronic Linguosynergetics). Synergetics in Philological Studies. Kharkov: V. N. Karazin Kharkiv National University, 20-61.

[9] Dombrovan, T. (2018). An Introduction to Linguistic Synergetics. Cambridge: Cambridge Scholars Publishing.152.

[10] Haken, H. (1977). Synergetics. An Introduction. (Springer Series in Synergetics). Berlin: Springer-Verlag. (3 ${ }^{\mathrm{rd}}$ ed. in 1983$) .325$.

[11] Haken, H. (1987). Advanced Synergetics. (Springer Series in Synergetics). Berlin: Springer-Verlag.358.

[12] Haken, H. (1990). Synergetics in Cognition. (Springer Series in Synergetics). Berlin: Springer-Verlag.438.

[13] Haken, H. (2000). Information and Self-organization: A Macroscpic Approach to Complex Systems (Springer Series in Synergetics). Berlin: Springer-Verlag.225.

[14] Jia, H., \& Liang, J. (2020). Lexical category bias across interpreting types: Implications for synergy between cognitive constraints and language representations. Lingua, 239, 102809.

[15] Kiyko, S. V. (2014). Omonimiya v movi ta movlenni. (Homonymy in Language and Speech). Chernivtsi: Rodovid.544.

[16] Kiyko, S. V. (2016). Synerhetyka omonimiyi yak movnoho, movlennyevoho i mizhmovnoho yavyshcha. (Synergetics of Homonymy as a Linguistic, Speech and Interlingual Phenomenon). Chernivtsi: Chernivtsi National University.532.

[17] Klymenko O. L. (2018). Vnutrishn'omovni transformatsiyi v slovnyku anhliys'koyi movy: synerhetychna perspektyva. (Intralinguistic Transformations in the English Language Vocabulary: a Synergetic Perspective). New Philology. Vol.74. P. 4348.

[18] Knyazeva, Ye. N. (2001). Samoreflektivnaya sinergetika. (Self-reflective Synergetics). Voprosy filosofii. (Problems of Philosophy).10. 99-113.

[19] Knyazeva,Ye.N., Kurdyumov, S.P. (2002). Osnovaniya sinergetiki. Rezhimy s obostreniyem, samoorganizatsiya, tempomiry. (Foundations of Synergetics. Regimes with Aggravation, Self-organization, tempoworlds). St.Petersburg: Aletheia.414p.

[20] Kuzeev, S. (2020). Language and Consciousness: Towards the Path of Synergy. Argumentum, 16, 230-240.

[21] Lan-xia, W. (2014). The Synergy of Language and Culture and The Formation of Language Value Meaning Space. Foreign Language Research, 06.

[22] Malinetskiy G. G. (2005). Predisloviye. Bezruchko B. P., Koronovskiy A. A., Trubetskov D. I., Khramov A. Ye. Put'v sinergetiku. Ekskurs v desyati lektsiyakh. (Preface. Bezruchko B. P., Koronovskiy A.A., Trubetskov D.I., Khramov A.E. Way to Synergetics. A Guided Tour in Ten Lectures). Moscow: DomKniga. 9-16.

[23] Pikhtovnikova, L. S. (1999). Synerhiya stylyu bayky: nimets'ka virshovana bayka XIII-XX stolit'. (Synergy of Fable Style: German Poetic Fable of the XIII-XX Centuries. Kharkiv: Biznes Inform.220.

[24] Pikhtovnikova, L. S. (2005). Stylistyka i synerhetyka dyskursu. (Stylistics and Synergetics of Discourse). Discourse as a Cognitive-communicative Phenomenon. Kharkiv: Konstanta.29-35. 
[25] Pikhtovnikova, L. S. (2009). Sinergeticheskiy metod dlya issledovaniya diskursa v pragmastilisticheskom aspekte. (A Synergistic Method for the Study of Discourse in a Pragmatic and Stylistic Aspects). Bulletin of Kharkiv National University. Romano-Germanic Philology. Kharkiv: Konstanta. 848.48-52.

[26] Pikhtovnikova, L. S. (2011). Teksty malykh form: Linhvosynerhetychna interpretatsiya. Dydaktyzatsiya. Pereklad. (Texts of Small Forms: Linguosynergetic Interpretation. Didacticization. Translation). P. I, Mariupol' : PDTU.160.

[27] Pikhtovnikova, L. S., Yaremchuk I. M. (2012). Dyskurs prytchi u synerhetychnomu aspekti. (The Discourse of the Parable in the Synergetic Aspect). Naukovi zapysky. Series: Philological. 26. Ostrog: Publishing House of the National University Ostroh Academy.266-269.

[28] Pikhtovnikova, L. S. (2015). Samoorganizatsiya diskursa i otdel'nykh tipov diskursa. (Self-organization of Discourse and Certain Types of Discourse). Synergetics in Philological Studies. Kharkov: V. N. Karazin Kharkiv National University.88-102.

[29] Prigogine, I. (1977). L'ordre par fluctuations et le système social. (Order by fluctuations and the social system). L'idée de regulation dan les sciences. Paris. 153-191.

[30] Prigogine, I. (1989). The Philosophy of Instability. Futures. 21. 396-400.

[31] Prikhodko, A. N. (2003). Sintaksis yestestvennogo yazyka v fokuse kognitivno-diskursivnoy paradigmy slovoobrazovaniya. (Natural Language Syntax in the Focus of the Cognitive-discursive Paradigm of Word Formation). Bulletin of Kharkiv National University. Romano-Germanic Philology. Kharkiv: Konstanta, 609. 84-89.

[32] Prikhodko, A. N. (2015). Samoorganizatsiya kontseptual'nykh sistem i mezhkul'turnyy transfer kontseptov (Self-organization of Conceptual Systems and Intercultural Transfer of Concepts). Synergetics in Philological Studies. Kharkov: V. N. Karazin Kharkiv National University.135-154.

[33] Selivanova, O. O. (2006). Suchasna linhvistyka: terminolohichna entsyklopediya. (Modern Linguistics: A Terminological Encyclopedia). Poltava: Dovkillya-K.718.

[34] Semenets, O. O. (2004). Synerhetyka poetychnoho slova. (Synergetics of the Poetic Word). Kirovograd: Imex LTD.338.

[35] Semenets, O. O. (2015). Synerhetyka modal'nostey poetychnoyi tvorchosti. (Synergetics of Modalities of Poetic Creativity). Synergetics in Philological Studies. Kharkov: V. N. Karazin Kharkiv National University.154-179.

[36] Simonov, K. I. (2013). Fraktaly v yazykovoy materii. (Fractals in Linguistic Matter). Moscow: Thesaurus.208.

[37] Tarasova, Ye.V. (1996). Samonastraivayushchiyesya sistemy i diakhronicheskoye izucheniye yazyka. (Self-adjusting Systems and Diachronic Language Researching). Bulletin of Kharkiv National University. Romano-Germanic Philology. Kharkiv: Konstanta, 386. 127-131.

[38] Tarasova, Ye.V. (2000). Sinergeticheskiye tendentsii v sovremennoy lingvistike (Synergetic Trends in Modern Linguistics). Bulletin of Kharkiv National University. Romano-Germanic Philology. Kharkiv: Konstanta. 500. P.3-9.

[39] Vasilkova, V. V. (1999). Poryadok i khaos v razvitii sotsial'nykh sistem. Sinergetika i teoriya sotsial'noy samoorganizatsii. (Order and Chaos in the Development of Social Systems. Synergetics and the Theory of Social Self-organization). St. Petersburg: Lan'.480.

[40] Veremchuk, E. O., Yenikeyeva S. M. (2020). Linhvokohnityvnyy ta linhvosynerhetychnyy parametry anhliys'komovnoho leksyko-semantychnoho polya SPACE/KOSMOS. (Linguocognitive and Linguosynergetic Parameters of the English Lexicalsemantic Field SPACE/COSMOS). Zaporozhia: FOP Mokshanov.244.

[41] Yenikeyeva, S. M. (2006). Systemnist' ta rozvytok slovotvoru suchasnoyi anhliys'koyi movy. (Systemic Character and Development of Word-formation in Modern English). Zaporizhia: Zaporizhia National University.303.

[42] Yenikeyeva, S. M. (2011). Fraktal'nost' mikrosistem slovoobrazovaniya (na materiale angliyskogo yazyka). (Fractality of Word-formation Microsystems (Based on the Material of the English Language). Studia Linguistica. Language in the Logic of Time: Heritage, Traditions, Prospects. St. Petersburg: Polytechnic-service, XX.107-118.

[43] Yenikeyeva, S. M. (2015) Sinergeticheskiye parametry strukturnoy organizatsii i razvitiya slovoobrazovatel'noy sistemy sovremennogo angliyskogo yazyka. (Synergetic Parameters of the Structural Organization and Development of the Wordformation System of the Modern English Language). Synergetics in Philological Studies. Kharkov: V. N. Karazin Kharkiv National University. 62-88.

[44] Yenikeyeva, S. M. (2018). Strukturna orhanizatsiya anhliys'koho rechennya yak fraktal'noho ob'yektu. (Structural Organization of an English Sentence as a Fractal Object). New philology. 73.27-33.

[45] Yenikeyeva, S. M., Klymenko, O. L. (2021). Synergy of Modern English Word-Formation System. Linguistics and Culture Review, Vol. 5, No S1. 2021. 1110-1122. https://doi.org/ 10.37028/lingcure.v5nS1.1495

Olga KLYMENKO (PhD in Philology) is Professor at the English Translation Department of Zaporizhzhia National University, Zaporizhzhia, Ukraine. Her areas of interest include synergetic linguistics, neology, discourse studies, socio-cultural and gender studies, onomastics. O. Klymenko is the author of 3 monographs, 2 textbooks, 2 dictionaries, and 70 scientific articles. Recent publications: "Ukrainian Orthodox Church Naming in Modern English Language Media", "Twitterverse: The birth of new words", "Linguistic Innovations Paving the Way For Language Democratization", "Communicative Behavior via Gender Identity (Case Study: The English language "Love Stories")", "Evolution of gender-neutral pronouns from W. Shakespeare to Modern Media", "Synergetic Principles of New Words Formation".

Saniya YENIKEYEVA (PhD, Dr. of Science in Philology) is Professor at the English Philology and Linguodidactics Department, Zaporizhzhia National University, Zaporizhzhia, Ukraine. The areas of interest include synergetic linguistics, cognitive linguistics, neology, discourse studies, lexicology, word-formation. S. Yenikeyeva is the author of 5 monographs, 2 textbooks and 77 scientific articles. Recent publications: "Allusive Anthroponyms in English Journalistic Discourse: Linguo-cognitive and Pragma-stylistic Aspects", "Synergetic Parameters of the Structural Organization and Development of the Word-formation System of Modern English", "Formation of Blendings on the Basis of Proper Names: Analysis of Lexical Innovations of Modern English", "Systemic 
Organization and Evolution of Language in the Light of Fractal Theory", "Linguo-cognitive and Linguo-synergetic Parameters of the English Lexical-semantic Field SPACE / COSMOS". 